\title{
GENDER DISCREPANCY IN ECONOMIC PARTICIPATION: THE CASE OF YOUNG WOMEN IN THE DEMOCRATIC REPUBLIC OF CONGO
}

\author{
Darla Urmiche Diya Lipoko \\ Chux Gervase Iwu $\boldsymbol{I}^{1}$ \\ iwuc@cput.ac.za \\ Abdullah Promise Opute \\ Department of Research \\ GPROM Academic and Management Solutions \\ Salzkotten, Germany, 33154 \\ ${ }^{1}$ Department of Entrepreneurship and Business Management \\ Cape Peninsula University of Technology \\ Cape Town, South Africa, 7535
}

$\triangle$ Corresponding author

\begin{abstract}
Given the patriarchal nature of the African society, females are often secondary. In patriarchal societies, men are viewed as forbearers of knowledge and hence dominate other considerations. A direct consequence therefore is structural discrimination of women, and small businesses are owned and managed by men. Youth unemployment is notably high in the Democratic Republic of Congo, and especially among females. Notably too, one critical factor that drives entrepreneurship start-ups is self-employment, often induced by unemployment. In patriarchal societies, not only are there few opportunities for women but also women face more constraints than their male counterparts. Inspired by the gap in the literature, this study utilizes the descriptive literature review approach to understand the problems, faced by young women when starting a business in Kinshasa, the Democratic Republic of Congo. Understanding this theoretical premise and from the perspective of the explored population is important given the criticality of entrepreneurship to economic growth (including unemployment and poverty reduction). In addition, this study would contribute to strategic policy change for achieving productive entrepreneurship. Finally, this study flags research directions for steering necessary research towards productive entrepreneurship goals.
\end{abstract}

Keywords: small business, female entrepreneurship, Small and Medium Enterprises, gender.

DOI: $10.21303 / 2504-5571.2021 .002121$

\section{Introduction}

Despite job scarcity in both public and private organisations, today's youth continue to pursue education, espousing the need for innovation and job creation [1]. The importance of entrepreneurship and small businesses in economic growth has, therefore, become globally recognised to provide employment for the youth and develop an economy sustainably. After all, studies have revealed that small and medium enterprises (SMEs) contribute largely to national employment [2].

While some countries are considerably advanced in integrating and promoting entrepreneurship and small business as economic and employment entities, others for various reasons, have not. For instance, a country that has experienced a civil war will have difficulty in harnessing resources for national development. It is common knowledge, that such countries are sometimes unable to maintain a stable and enabling business environment [3]. The Democratic Republic of Congo (DRC) is among those countries that have experienced civil war and is still experiencing instability in the east of the country. The DRC's unstable business environment (political instability, negative economic growth, and crisis in the east of the country) makes it difficult for most young Congolese to venture into business. In the past years, the DRC was one of Africa's economic giants. Today, instability and longstanding civil wars in the eastern part of the country have left 
the DRC olitically unstable and economically less attractive to potential investors [4]. One of the solutions for economic underperformance is to support and develop entrepreneurship [5].

The DRC is a predominantly French-speaking country, located in central Africa with eight neighbouring countries, comprising Angola, Burundi, Central African Republic, Republic of Congo, Rwanda, South Sudan, Tanzania, Uganda, and Zambia [1]. The DRC has an estimated population of 91 million inhabitants. Kinshasa, the capital of the DRC, is one of the largest cities in sub-Saharan Africa, with a population of about 17 million people, living in 24 suburbs [6]. This study focuses on the DRC's young female population in Kinshasa and the difficulties they face in venturing into small business activities. According to the DRC's National Youth Policy, Congolese youth are between 15 and 35 years old [7]. Many of those who engage in entrepreneurial activity do so for survival [8]. In other words, they are survival entrepreneurs, and the reason for their being survival entrepreneurs could be because they do not have the right tools owing to literacy, or lack of finance [9] are indeed obstacles to the uptake of business activity in DRC [10].

Acknowledging and understanding the problems, faced by any country or its population regarding opening a business, is important because through business practices, revenue is created, and unemployment can be reduced. Basically, business activities generate employment opportunities, and these opportunities ameliorate the living standards of people [11]. This study explores factors that discourage young women from starting a small business and entrepreneurship activities, and the obstacles to business and small business growth in Kinshasa. A core contribution of this research therefore lies in its capacity to illuminate the state of knowledge towards driving policy change and stimulating future research for the purpose of achieving productive entrepreneurship. Additionally, the contribution of this paper extends to finding answers to the continued underrepresentation of women, especially young women in DRC's business ecosystem.

\section{Materials and Methods}

We set out to find out the difficulties, faced by DRC's young female population in Kinshasa in venturing into small business activities, and how these difficulties translate to pitfalls for the DRC economy. To do this, the qualitative approach [12] was utilized in this study given its suitability towards gaining a detailed understanding of existing knowledge in a domain [13]. Specifically, this study is based on the use of the descriptive literature review method. This is a methodological practice that has gained acceptance for conceptualizing, surveying, and synthesizing relevant publications for a research project [14]. With the intention of revealing an interpretable pattern from the existing literature $[15,16]$, we began by conducting a comprehensive search for relevant publications, drawing from [17] that argue that in a descriptive review, every publication counts. Thus, our review was not restricted to only journal articles despite [18] claim that only journal articles represented authentic science. We were convinced that this approach would facilitate the uncovering of current materials [19] in Kinshasa, DRC in relation to the difficulties that young females encounter during the setting up of a small business. However, to ensure that the pool of literature reviewed in this study reflected academic quality, a systematic approach [20, 21]; [13] was followed in capturing only publications where the contents have been adequately referenced. To ensure adequacy of literature for this study, we followed the methodological counsel [22] that argues that the conditions for selecting documents, or for focusing on topics, ought to reflect the goals of the study. For that purpose, too, a literature search was conducted through Google Scholar as well as a desk search for keywords [20, 21], such as 'young women businesses in Kinshasa', 'challenges of small businesses in Kinshasa', 'growth prospects of businesses in Kinshasa', amongst others. The review enabled the emergence of the following thematic structure, upon which the discussion of the basis of this paper is organised.

This paper is presented in the following order:

- Factors that discourage young women from starting a business in Kinshasa

- Challenges that inhibit the growth of small businesses in Kinshasa

- Prospects for the growth of small businesses in Kinshasa

- The effects of challenges, faced by young Congolese women in entrepreneurship 


\section{Result}

\section{1. Factors that discourage young women from starting a business in Kinshasa}

Being a young entrepreneur is a huge responsibility; therefore, strong support is needed to succeed [23]. A common source of support for the budding entrepreneur is the family [24]. Unfortunately, most families would rather nudge the aspiring entrepreneur to seek paid employment instead of starting a business [25]. However, it is recently noticed, that more families are now trying to understand the good impact of supporting their young entrepreneurs [26]. It is necessary for the nation to discover approaches to engage women's interest and accomplishment in enterprise through manageable and fruitful financial improvement [27]. Most of the start-ups do not get support from government [28]. The World Bank [29] explained that despite the good intention from the DRC's government to support entrepreneurs, the struggle is still real to create the needed support. National law and regulation of business registration are never-ending processes or almost impossible steps to be completed by a new entrepreneur. To add to the difficulties, banks require business registration papers to grant a loan. In the DRC, the situation is rather more complicated, with young people, having to face various difficulties. These impediments are inter-related. However, among them, the key issue remains the lack of financial resources. Other hindrances include the absence of trust and security, occurring in credit application procedures to financial organisations [30]. An African Business Angels Network organiser contends that despite these demonstrated obstacles, the country is fighting to bring financial and moral support to entrepreneurs [31]. Generally, in the DRC, donors concentrate on humanitarian rather than financial help. There are a few private sector advancement programmes in the DRC, for example, ÉLAN RDC, that take an interest in helping youth-owned business enterprises.

A Congolese educator explains that the DRC's requirements for business visionaries to make and create organisations and employment across the country are problematic [32]. For instance, Congolese tertiary and secondary education programmes do not offer entrepreneurship courses, except for a few private institutions in the capital [33]. This is an indication that entrepreneurial education is at a low level. If the Congolese government were to incorporate an entrepreneurial culture in the education curriculum, they would generate more and better young entrepreneurs in the country, considering that youth and women represent more than half the country's population [34]. An entrepreneurial culture and education can be incorporated into general training programmes in various ways in the DRC. For example, this could encompass a cross-curricular methodology, coordinated with existing subjects or could be presented as a self-standing educational programme. Where coordinated with existing subjects, this is frequently discretionary.

Remaining faithful to old cultures, customs or traditions are a further obstacle for young women who wish to participate in business in the DRC [35]. Contravening the cultural and or customary codes brings about sexual violence against the woman [35]. Some customs in DRC do not see the importance of women education. Women do not have to go to school or learn any entrepreneurial activity, as parents mostly invest in their boys in terms of education rather than in their girls. For these parents, girls are supposed to get married and start their own families from the age of 15 . If a woman reaches the age of 20 without being married and having children, she is mocked and ostracised by her parents and forced to leave the family home [36]. What is clearly wrong in DRC society, the way traditional practices and social convictions have converged with misinterpretations of religious scripture from the Bible. Despite this traditionalism, change and improvement are now discernible in various cities and areas, mostly in the capital, Kinshasa. Young women study at universities, become well educated, and work in modern institutions, and are in no hurry to get married or start a family [37].

It is fundamental to understand the connection between education and health, and its impact on economic improvement. The DRC training framework is undermined by its limited inclusion and low quality of education and health services [38]. An estimated 3 million children of elementary school age are not in school. Of those who do attend school, they start late after the age of six. Not all children who enter the first grade will finish the sixth grade, and of those individuals who reach the sixth grade, not all of them will reach the exit level, which is the final examination to obtain a qualification [39]. Over the years elementary schools in the DRC have increased, with 
enrolments going from approximately five million to 13.5 million. Nevertheless, almost $50 \%$ of these primary school learners will drop out before finishing school, adding to those who never registered, including the 3.5 million children who stayed out of school [40]. This school attendance disproportionately affects young women relative to young men. Elementary schools also show low learning accomplishments, with a high proportion of learners, not completing essential or exit examinations. In the eastern parts of the DRC, the accelerated learning programmes are viable in offering learning opportunities to out-of-school youth. They compress what could be compared to the six-year essential programme into three years, enabling learners to meet the basic requirements for professional training. There are also new programmes for schools to improve learning, especially for young women, by educating instructors, directors, tutors, and the parent-educator relationship on sexual orientation [41]. These school programmes are organised according to three tactical objectives:

1. Developing access and guaranteeing value

2. Improving the nature of learning: this intends to improve quality

3. To improve the administration and oversight of the standards and systems for overseeing assets and improving administration at all levels [41].

In the DRC, the wellbeing of the population is a major concern when health issues, such as malaria, diarrhoea, lower respiratory tract infections, HIV, preterm birth and tuberculosis, are common [42]. Young women in the DRC are especially powerless as they frequently experience early marriages, undesired pregnancies, and sexual abuse [43]. The low use of condoms (27\%) and incidence of families arranging marriages (5\%), combined with high premature birth rates, make young women vulnerable to poor health. In the DRC, sexual health-based zones can offer regenerative health to only $15 \%$ of youth [44]. The DRC possesses $52 \%$ of Africa's surface water resources (lakes, wetlands, waterways). The DRC is the most water-rich nation in Africa, with an annual rainfall precipitation of around 6000 billion $\mathrm{m}^{3}$ with groundwater, estimated at nearly $47 \%\left(421 \mathrm{~km}^{3} /\right.$ year) of the DRC's sustainable water assets [45]. Despite huge water supplies, the main health challenges of the DRC remain the lack of potable water and a large part of the population is reliant on groundwater as safe drinking water [46].

The DRC has over 80 million hectares of arable land and more than 1100 recorded minerals with a variety of metals. The DRC could potentially have the most flourishing economy on the continent and be a driver of African development on the off chance that it can rid itself of its political insecurity and improve its governance [47]. DRC is a low-income country because of poor governance and political instability with current civil war in the east of the country. The poverty rate decreased from $69.3 \%$ in 2005 to $64.0 \%$ in 2012; however, the total number of those, living below poverty lines, increased by 7 million, possibly owing to the rapid population growth. As the Table 1 demonstrates, there are disparities in the distribution of poverty across provinces in the DRC. Essentially, poverty is rife in the DRC and with poverty comes varieties of society's ills.

Table 1

DRC's poverty rate per provinces in percentage

\begin{tabular}{cc}
\hline Some Provinces in the DRC & Percentages of poverty \\
\hline Bandudu & $77.2 \%$ \\
Equateur & $76.4 \%$ \\
Kasai Oriental & $75.9 \%$ \\
Nord-Kivu & $49 \%$ \\
Bas-Congo & $49.3 \%$ \\
Sud-Kivu & $62.9 \%$ \\
Kinshasa the Capital & $52.8 \%$
\end{tabular}

Source: [48]

The cost of bread, rice, cornmeal, and palm oil are always rising, more urban families saw their stable living conditions disintegrate [35]. Family units reliant on cornmeal saw the cost of consumption increase. The wages of community workers, apart from those in security adminis- 
tration, decreased. Additionally, nourishment allowances were cut from soldiers and in the private sector; businesswomen, called 'maman va zando' (micro-businesswomen), also experienced the consequences of the Franc's depreciation.

Food and nutrition are big issues in DRC. Women are less likely to earn high salaries and are more likely to be dependent and poverty stricken. This militates against the private sector's allocating resources to Congolese businesswomen, as their businesses give the impression of being less productive. This profitability trap sustains a cycle of endless need, destitution, and poverty of women, from which it is hard to escape $[49,50]$. In the first place, poverty maps are being created that will help improve the geographic focus of poverty alleviation programmes. Secondly, given the high urban indigence rate and rapid urbanisation in the nation, another project is being created with the objective of identifying living conditions in urban regions, especially in Kinshasa [51]. The dependency is high and has different aspects, about five million people in the country depend on their loved ones for their basic income, some depend on humanitarian help or external aid for basic needs, such as food or health [52].

\section{2. Challenges that inhibit the growth of small businesses in Kinshasa}

It is known internationally, that SMEs are the engines that drive financial advancement. In Africa, various SMEs face challenges, ranging from inconsistent power, limited access to capital, poor administrative capacity and lack of information. It is astounding, that most African governments give no assistance to SMEs, thus ignoring important engines of growth [53]. South Africa (SA) is one of these African countries where SMEs represent over $60 \%$ of businesses and jobs, contrasted with a worldwide average of $77 \%$. In addition, South African SMEs have an extremely high failure rate. The minister of trade and industry has noted that most SMEs fail in their first year, with one of the highest failure rates globally. Significant factors that affect South African SMEs include interest rates, trade rate expansion, unemployment, crime, AIDS, and government incapacity. In this case, the government and non-governmental organisations need to regulate conditions, improve access to various business sectors and funding, attend to the skills shortfall, and empower better access to data [54].

One of the challenges, also facing the Congolese population, is that the law allows individuals 30 years and older to own a business, which explains the high level of dependency. In fact, more than half the people depend on others financially [55]. The Fig. 1 below presents the DRC population in terms of age. The Fig. 1 illustrates that people from 15 to 64 years old are the majority, followed by those under the age of 15 . The lowest population group comprises persons above 64 years old.

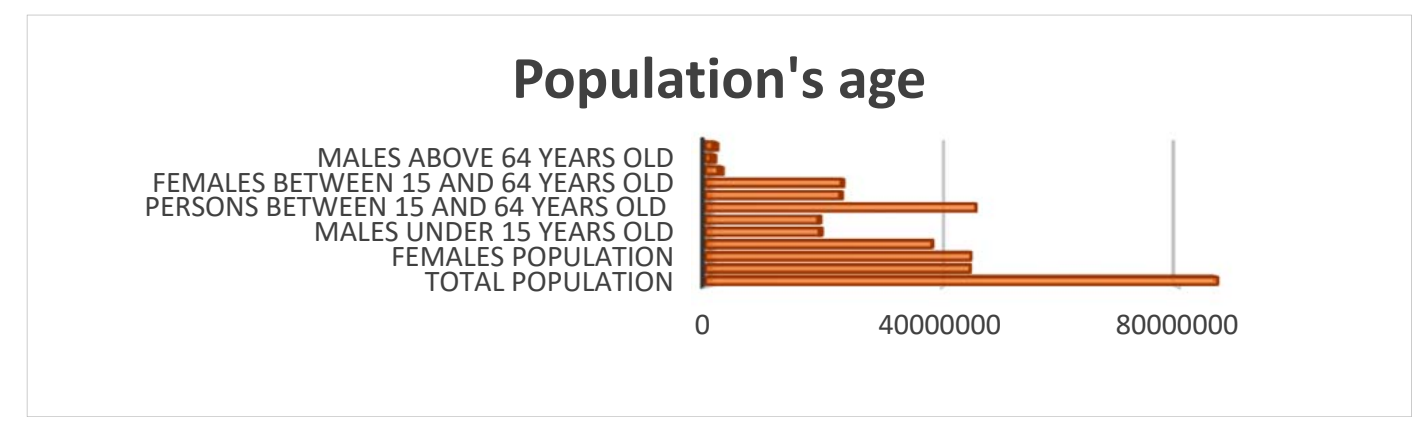

Fig. 1. DRC's population in terms of age. Source: [56]

When Belgium colonised the DRC in the early $20^{\text {th }}$ century, it attempted to impose its systems and entrenched local customs by influencing individuals. This to some extent resulted in the DRC's post-independence turbulence, affected by uprisings and secessionist wars [57]. The wars disturbed financial movement in key segments. It is important to note that most African nations are not in crisis because they are poor, but instead, their assets create their crises. These assets, which could be utilised for state and country building, are the cause of endless civil wars [58]. The 
DRC has nine neighbours, the largest number on the continent, which comprises a gigantic market for DRC products and goods. The high volume of casual exchange suggests the potential scale of trade [59]. A key drawback is that the nation faces security incursions from its neighbours. The political instability and conflict in the DRC have resulted in clashes for decades that have affected endeavours to mitigate poverty, improve the economy, and impose stable administration and the principles of law. Many foreign rebel forces and state armies are found in the eastern regions of the nation [60]. One of the reasons, engendering recent political instability in the DRC, is because the presidential elections were postponed for two years. This created more political turmoil [37]. The DRC needs help to develop vision to improve administration and state governance [61]. Further, addressing corruption is a long-term challenge. In the event, the International Monetary Fund (IMF) is driving financial reform, particularly with regard to improving administration and state governance, focusing on anti-corruption measures - possibly a simpler means to achieve critical positive change.

Gender inequality occurs when men and women do not have equal treatment or conditions to realise their full human rights in social, cultural, economic, and political spheres. It is in this regard, the imbalance of similarities and differences of men and women and their roles, perceived by society, must be noted [2]. In sub-Saharan African countries, sexual orientation and gender inequality are rampant. Women struggle to start new pursuits and gain access to funding from commercial banks. The DRC's level of permanent workers with formal training is very low, whether for men or women. As indicated by access to finance, just $3.57 \%$ of women oversee firms that have a credit extension or an advance from a financial institution, while that proportion is $9.34 \%$ for men. In addition, $7.14 \%$ of women managed firms that had obtained an overdraft, against $9.34 \%$ of male-managed firms. Women mostly obtain resources or support from others, such as friends or family, who are used as intermediaries or back-up social capital. The proportion of female business owners, using informal methods of financial support, is $85 \%$ compared with $58.24 \%$ for men [62]. Despite the discrimination against women, there has been some improvement, like the family code of the DRC. For instance, married businesswomen in the DRC are now permitted to establish formal organisations, open bank accounts, register a company and perform a large range of other monetary transactions without support from their spouses [63]. Furthermore, Young women's progress from school to work is much more extended than that of young men. In the labour market, managers regularly favour employing male youth over female youth. This suggests that young women, especially young single mothers, are increasingly subject to underemployment, discrimination, and sexual harassment. Male domination, early marriage and discrimination are thus factors that impact young women's self-confidence to work in specific kinds of industry [64]. It is therefore not surprising, that the average job opportunities accessible in the market are mostly dedicated to or profiled for men.

Tax collection furnishes governments with the assets to put resources into general improvement, poverty reduction and effective public administration. It offers a means of achieving self-reliance in developing nations, giving financial independence and support that is expected to advance development [65]. Taxation on family units is high in the DRC. Information from the family survey shows that formal and casual payments average $11 \%$ of all family units, with middle-class family units reporting $7 \%$ of expenditure [66]. Average tax returns constitute about $16 \%$ of total family unit consumption and reach a pinnacle of practically $20 \%$ of family consumption in Kinshasa and Goma. These direct taxes are higher than direct taxes even in developed countries [66]. Nevertheless, a significant number of these payments do not flow into the government's budget account as tax payments. It is entirely conceivable, that $85 \%$ of all instalments from state authorities is not recorded in government spending plans, and that about $90 \%$ of all instalments do not reach the state. The tax loss cannot be translated as lost income that should be brought into government spending plans by rectifying enforcement, as payment may fail to reach the state for a variety of very different reasons [66]. Middle-class tax returns by female-headed family units are high, while the figure for male-headed family units is low. This is driven principally by larger payments for basic public services, such as water, health, power, and sanitation [67]. Tax authorities have easy access to companies' data information; that is why tax persecution has expanded. Tax laws are questionable in 
the DRC, so inexperienced businesses make for ripe pickings for the tax inspectors, who currently make demands even before assessing income [33].

Corruption is defined as the use of public resources and property for personal use [68]. Poverty is significantly impacted by corruption, tax avoidance, and generally poor tax organisation in developing countries [69]. Africa loses more than US\$ 50 billion in unlawful financial outflows as governments and international organisations participate in illegal and corrupt schemes. In various sub-Saharan African (SSA) countries, income deprivation exists because of illegal activities, which constitute $5.7 \%$ of GDP annually. This income deprivation obstructs progress and denies poor nations access to urgent administrative services [70]. Endemic corruption in the DRC permeates all parts of society. The DRC performed badly on all the measurements of administration surveyed [71]. There was no improvement in any of the country areas, with the lowest score for government adequacy. However, more recently, during the post-struggle period, there have been some signs of progress against corruption [72]. More than $50 \%$ of supervisors thought that corruption was a significant or extreme impediment to business development [73]. Therefore, fighting corruption can produce benefits for businesses and progressively aid administration and governance.

\section{3. Prospects for the growth of small businesses in Kinshasa}

The DRC is the second-largest country in Africa, comprising 2.26 million square kilometres, while Algeria, the largest, comprises 2.38 million square kilometres. The fourth largest in terms of population, it has rich natural resources, including $55 \%$ of the world's cobalt production, copper, gold, tantalum, tin, with $21 \%$ of precious stones and industrial diamonds, and $12 \%$ of tantalum and oil. It has copious water assets, adequate for farming and ecological protection [74]. In addition, it has enough to provide the whole of Africa with electricity [59]. It has the second most significant agribusiness potential in Africa, with more than $60 \%$ of the second largest forest basin and carbon stocks on the planet, and generous fish and domesticated livestock assets. To put it plainly, what occurs in the DRC matters to the whole African continent's future. It is expected, that the DRC should have a steady and prosperous economy that is able to help Africa reach its financial and economic potential in the twenty-first century [75].

\section{DRC's natural resources in percentages}
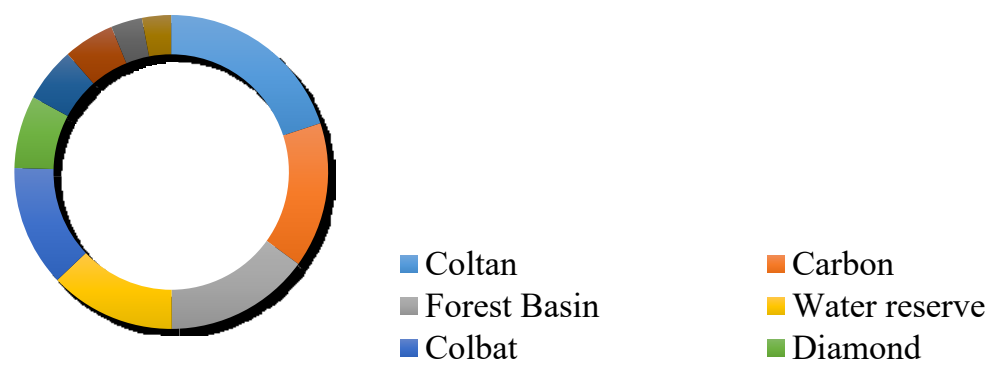

Fig. 2. Some of DRC's natural resources in percentages. Source: [75]

The mining and handling of minerals constitute a large proportion of all home production $(11.5 \%)$. This has been the primary driver of on-going development. While minerals and oil account for the largest proportion, other resources are also significant. There are large water resources (Fig. 2), significant for transport and hydropower generation [76]. The DRC is also endowed with fruitful land due to abundant rainfall and volcanic soil in the eastern and northern areas. Its steady contribution to food security and agriculture also provides a potential springboard for industrialisation. Cassava is the most broadly cultivated crop, with other cash crops, including tobacco, coffee, sugarcane, cocoa, rubber, and palm oil. The DRC has an expected 80 million hectares of accessible arable land with just $10 \%$ under development [77]. In the recently released Plan National Stratégique du Développement (PNSD), the nation's first national improvement plan centres on making the DRC a developing business economy and emerging market by 2030 and a 
developed nation by 2050. It is observed from the current literature, that the DRC is a large country in terms of population and size, as well as natural sources. Despite governance and political irregularities, the country offers significant developmental potential and investment opportunities. Financially, the DRC is of considerable interest to many business and commercial investors because of its huge reserves of natural resources.

\section{4. The effects of challenges, faced by young Congolese women in entrepreneurship}

Unemployed youth from the age of 15 to 24 years refers to those young people without work and relates to the capacity and legal status to work [55]. Participation rates among women remain significantly lower than those of men despite their higher number in terms of population (Table 2). We argue in this paper that a continued marginalisation of young women from participating in mainstream economic activities increases the rate of unemployment among them. This is especially striking in northern Africa, the Arab states and southern Asia, where the gender gap in economic participation remains at more than $50 \%$ [78]. Such wide gender inequality gaps are driven by a low rate of female participation; in the Arab states at $18.9 \%$, northern Africa $21.9 \%$, and southern Asia $27.6 \%$. These low rates are ascribed to a variety of socio-financial and sociocultural factors, which restrict female participation in the labour market. Female workforce support remains low, and women face more difficulties than men. Young women regularly drop out of school because of early marriage and pregnancy, hence leading to a gender gap in training. Numerous young women in rural areas that are obliged to perform family chores every day instead of attending school can also explain that gender gap. Women have $8 \%$ less access to skilled employment in contrast to men in paid work (12\%), and they are generally less well represented in the labour market outside the agricultural sector [79]. Among 15 to 24-year-olds, the female-male ratio of unemployment is $104.8 \%$. Women's work for the most part is found in subsistence farming $(70 \%)$ and private ventures in the informal sector $(60 \%)$. Only $2.8 \%$ of salaried professionals are women. The provincial or rural population represents $70 \%$ of the entire country's population, $60 \%$ of whom work in agriculture [43].

Table 2

DRC's unemployment rate in percentages

\begin{tabular}{ccccccc}
\hline $\begin{array}{c}\text { Total popula- } \\
\text { tion of men (\%) }\end{array}$ & $\begin{array}{c}\text { Total popula- } \\
\text { tion of women } \\
(\%)\end{array}$ & $\begin{array}{c}\text { Total popula- } \\
\text { tion of youth } \\
(\%)\end{array}$ & $\begin{array}{c}\text { Total unem- } \\
\text { ployment rate } \\
(\mathbf{\%})\end{array}$ & $\begin{array}{c}\text { Unemployment } \\
\text { among men (\%) }\end{array}$ & $\begin{array}{c}\text { Unemployment } \\
\text { among women } \\
\text { (\%) }\end{array}$ & $\begin{array}{c}\text { Unemployment } \\
\text { among youth } \\
\text { (\%) }\end{array}$ \\
\hline 49.07 & 50.03 & 58 & 10.40 & 6.7 & 9.4 & 7.75
\end{tabular}

Source: [43]

Only one out of every 20 working-age adults under 25 years has an occupation. The relationship between unemployment and education is not fortuitous, because many of jobless youth do not have any further training or tertiary education [64]. In some areas of the DRC, young people between the ages of 15- and 24 experience huge obstacles in finding employment. Because of instability in the east of the DRC, as well as social and economic conflict in the rest of the country, many people are financially and topographically marginalised and excluded. There are no social security plans or programmes to enable women to cope [80].

Poverty leads to prostitution [81]. Despite its richness in natural resources [82], the DRC is rife in poverty [48]. A poverty-stricken nation is a likely location for prostitution; poverty and deplorable living circumstances induce prostitution [83]. Prostitution is emanating from poverty, and that considering the level of education [84], and unemployment among the youth, the rate, at which the youth of DRC take up prostitution and or transactional sex, will continue to soar [64].

The youth are the most vulnerable in the DRC because they possess poor education, and minimal skills, which are exacerbated by poor economic challenges [64]. To escape deprivation, they engage in transactional sex for the purpose of accessing essential needs [84]. In the small-scale mining regions of north and south Kivu in the eastern Congo, women must engage in value-based sex to access job opportunities, thus establishing the connection between financial and sexual 
abuse [85]. Evidence from various settings suggests that young people feel compelled by their parents to engage in value-based sex to feed the family [85]. The main class of sex workers in the DRC comprises poor women, ousted from their community and who receive minimal resources or help from their families or spouses [86]. They engage in prostitution to survive. There are other women who enter prostitution, following early pregnancy, social rejection, or neglect [85]. An estimated $61 \%$ are in the range of 15 to 24 years old, and they are usually procured for US\$ 1 to US\$ 10 per sexual act. Although the extent of prostitution is unknown, adult and adolescent prostitution occurs throughout the country, and there are reports of women and adolescent girls, being coerced to engage in prostitution by their families [85].

There are several street children in the city of Kinshasa, and the figures have multiplied since the last decade. Kinshasa has a population of approximately 17 million people [87]. The urban spread of Kinshasa, combined with a high birth rate, has contributed to the large number of street children. In a delicate post-conflict economy, children, living on the streets, are helpless against young troopers who frequently engage in sexual misconduct [88]. On-going clashes in the east of the DRC have caused the displacement of families. Lack of educational resources and teaching makes it difficult for orphans and street children to be educated and live an ordinary life. Poverty and illiteracy lure children to be drafted into rebel groups. Most youngsters, enlisted by rebels, have no formal training [87]. The number of children and young people who have seen or experienced savagery in the DRC is apparently high. They are left damaged and mentally traumatised [89]. Adolescent misconduct or delinquency is not seen only in the city of Kinshasa or in the DRC; it is a worldwide phenomenon [90]. There is a category of homeless children in the DRC, known as kuluna, gangs of adolescents, living on the streets. Most are adolescent boys of 13 to 25 years. Kuluna gangs engage in savagery, robbery, and assault. These children are uneducated and do not have any support from family, government, or society. They are usually violent; they steal, are aggressive and view assault as the only way of surviving. Poverty, lack of distraction and dropping out of school at an early age impel these children onto the streets.

In recent years, worldwide, migrants have increased significantly [91]. Global migration has turned into a reality with increased interconnectivity in search of work, occupation, opportunity, instruction, personal satisfaction, or better quality of life. Sometimes caused by poverty, conflict, and unemployment. DRC faces critical urbanisation and delocalisation. Congolese abroad constitute a diaspora of 9000000 individuals who transmit an estimated US\$ 9 billion per annum, which is close to $30 \%$ of the DRC's GDP [92]. Congolese populations of more than $5 \%$ are either refugees or migrants around the world, and that women represent more than half of that total migrant population [93]. 100700 migrants from the DRC live in Organisation for Economic Co-Operation and Development nations [92]. Of these migrants, $25 \%$ do not have secondary education or training, but $32.5 \%$ have tertiary education. Undocumented Congolese who migrate from the country find it difficult to return to the DRC. In Europe and Africa respectively, France and South Africa are the most preferred destinations for Congolese migrants. In many Congolese communities, it would be surprising to find a family without a relative, living abroad, and these exiled people are frequently the hope of the entire family, viewed as essential providers for the relatives, staying at home [94].

In the DRC, all the provinces depend financially on the assets, sent from the capital Kinshasa. Each province generates assets that are directly sent to Kinshasa, and thereafter Kinshasa apportions a specific budget to each province [95]. Notwithstanding, the dispatched budget to each province is low and misused [96]. Kinshasa is the second densest city in Africa after Lagos in Nigeria. The country is encountering rapid rural urban relocation, with $35 \%$ of the population, living in urban zones, and an urbanisation rate of $4 \%$ [97]. Conflicts, affecting the eastern territories for more than two decades, have destroyed certain areas of the country [98], causing far-reaching instability and huge population displacement from the North Kivu, South Kivu, Ituri, Tanganyika, Haut-Katanga, and Kasai regions [99]. The capital, Kinshasa, is more secure than other provinces in terms of job opportunities, wealth, education, security, and many other essentials. Therefore, many people prefer to leave rural areas and relocate to the capital or other urban areas of the country to seek better livelihoods, while those that cannot fulfil their needs in the rural areas or in the capital prefer to relocate overseas to seek better opportunities or education [97]. 
The low number of young women, involved in small business and entrepreneurial activities, is also due to an endemic culture of gender inequality and unfair discrimination in the DRC [100]. The low number of young women, involved in small business and entrepreneurship, is the reason of lack of opportunities for women and youth to contribute to economic development and regulations. For example, the lack of access to credit and training limits the potential for women and youth to create viable businesses, which may create jobs [101]. Women in politics or in government positions are problematic for DRC societies, who prefer men in such roles, not trusting women's abilities [102]. Based on this sort of discrimination, many Congolese women are not confident to enter politics and do not believe they can succeed in a man's world. In the eastern part of the country, almost the entire population of women have been raped and are still being raped because of unresolved political issues in that specific region [103]. These women and young girls are traumatised for life; they do not have the courage to do anything and feel useless and abused. They are afraid to leave home, and do not believe they can restart their lives. In a country where women are more representative of the population than men, and where youth constitute more than half of the entire population, the loss of these women and youth is highly problematic, as they could generate important economic growth if protected and supported in business. Congolese women are reputed to be hard workers, especially in agriculture [104].

In the $\mathrm{DRC}$, most of the businesses are micro, small, and medium-sized enterprises [105]. More than $90 \%$ of ventures are small, with one to nine representatives, and almost $50 \%$ of them have been running for less than five years. However, firms six years and older contribute to most jobs in the DRC (around $60 \%$ ). Young firms represent more than $35 \%$ of all businesses and jobs. When contrasted with other fragile and conflict-affected states (FCSs), for which enterprise surveys are available, the DRC emerges at the top, just second to South Sudan [105]. Single mothers and young women are the victims in business failure. If a woman has business potential and starts a business enterprise, that business will progress very slowly or will fail completely because the entire income will be used to take care of the children and family. Success and perseverance therefore are difficult. These women start businesses not because they want to be entrepreneurs or businesswomen, but because they need some income to take care of their families. Succeeding under such conditions can be difficult [106]. Not all organisations that apply for loans are successful [62]. A significant number of credit applications were declined, as $53.2 \%$ to $83.5 \%$ of individuals who applied for funding did not get it. This gives tangible proof of current limitations, regarding obtaining financial support from financial institutions in the DRC. This suggests seed funding is one of the significant difficulties, experienced by SMEs in the DRC. Almost all entrepreneurs rely on their families, friends, spouses, or colleagues as sponsors to support them financially. It is even more difficult for women to obtain financing, as banks doubt that businesswomen will be able to repay loans. In the rare cases that start-ups are funded, the funding is allocated mainly to men. Therefore, it is not surprising to note that most business failures are among businesswomen [62]. When companies and individuals explain their business challenges and what causes their ventures to fail, the DRC's electricity issues in general and in Kinshasa are the most common reasons for business failure. Businesses without a generator are inclined to fail, as load shedding occurs daily for long hours and sometimes for days [107].

\section{Discussion}

The government can play a significant motivational [9] and facilitating [108] role in driving productive entrepreneurship. Motivationally, the government can steer strategic entrepreneurship education. The government can engage actively with education providers to design educational packages, strategically training entrepreneurs towards economic growth, impacting entrepreneurship. To succeed entrepreneurially, entrepreneurs would need to recognise the criticality of strategic marketing and innovative mechanisms [109]. Government educational mechanisms could therefore include measures that enable young and women entrepreneurs to understand the strategic marketing and innovative approaches that would enable entrepreneurial success. As a facilitator, the government can engage intensively with entrepreneurs and strategic actors to provide necessary financial and supportive plans to enable young and women entrepreneurs to achieve productive 
entrepreneurship. Literature about SSA suggests entrepreneurship in this context is largely survivalist natured $[9,110]$. In this facilitating function, the government can initiate a hands-on-deck approach of working closely with such entrepreneurs (women and otherwise) to identify and support them with their core needs towards achieving entrepreneurship that contributes to economic growth. To achieve that target, such hands-on-deck initiatives could also involve government, providing entrepreneurial skills, enhancing support to women entrepreneurs. Within this target of facilitating women entrepreneurship, the government would need to give due attention to gender inequality and discrimination against women. More effort should be invested into supporting them. Often, women who engage in entrepreneurship have families and are often faced with the challenge of coping with the dual stress of attending to their families as well as navigating their entrepreneurship journey. Therefore, governmental hands-on-deck tools could also include providing adequate supporting facilities, for example, nanny centres and after-school packages for entrepreneurial women who may need such.

Study Limitations. Like every piece of research, this study has some limitations, one of which relates to the descriptive review nature of this study. While a rigorous review approach was taken towards capturing a substantial pool of literature and the core debates in the literature, we recognise that some relevant literature to the focus of this study may have been ignored. In this regard, it is important to note, that we may have been limited by the keywords we considered in this study. Furthermore, with regards to the thematic conclusions, made in this study, we acknowledge that focusing strictly on literature that relates strongly to the geographical context, sensitised in this study, and ignoring relevant literature from other contexts may have affected the extent, to which the conclusions in this study can be transported to other contexts.

Future Research Directions. As mentioned earlier, the literature on entrepreneurial start-ups amongst women and in general in Kinshasa, Democratic Republic of Congo, challenges and success and failure outcomes are very scanty. To achieve active entrepreneurship that would drive economic growth as documented in the Western context $[109,111]$, more research efforts should be invested into exploring the sub-Saharan Africa context $[9,110]$. In that regard, further research of this nature should be undertaken to clearly understand the state of development towards embracing necessary initiatives for improving entrepreneurial uptake and drive. Also, empirical research could be undertaken to highlight the challenges from the points of start-ups and management of such entrepreneurial initiatives. Furthermore, in that regard of start-ups and management, the government can play a major role. Research should expose knowledge about this role and highlight appropriate enhancement initiatives in that regard. For example, literature on the sub-Saharan Africa (SSA) setting suggests that entrepreneurship activity in this setting is relatively survivalist $[9,110]$. Research could therefore illuminate the core challenges, faced by women entrepreneurs and entrepreneurs in general in that setting, and offer relevant guidelines for overcoming those challenges towards achieving economic growth, impacting entrepreneurship. The lack of government support has been underlined as one major entrepreneurship challenge in the SSA setting $[9,112]$. Future research could shed more light on this challenge for women entrepreneurs as well as other entrepreneurs. Finally, future research could focus more on the entrepreneurship education component with a view on highlighting approaches for achieving active entrepreneurship amongst women in the Kinshasa setting, and Africa in general.

\section{Conclusions}

From the reviewed literature, entrepreneurs (conceptualised to include young and women entrepreneurs) face immense challenges both from the points of entrepreneurship start-ups as well as success prospects. One of the major challenges, faced by these entrepreneurs, relate to lack of exposure to adequate entrepreneurship education. Since these entrepreneurs are not exposed to such entrepreneurship training, they lack relevant skills for making the right entrepreneurial decisions. Further on the point of education, reviewed literature indicates that a large percentage of these entrepreneurs lack basic education and therefore lack the educational capacity to appropriately process entrepreneurial decisions. Another critical challenge that entrepreneurs in the focal geographical premise face relates to lack of support from the government. Neither does the government 
support them with necessary finance to enable their start-ups nor is necessary financial support provided to enable them to implement their entrepreneurial initiatives. To the contrary, unlike in Western societies where young entrepreneurs (beginners) may be granted tax benefits, young and women entrepreneurs in Kinshasa, Democratic Republic of Congo are obliged to pay tax in their early operational years. It is also documented in the literature, that banks would rarely grant loans to women entrepreneurs. Corruption is also noted as one of the core factors that account for the unfavourable entrepreneurial situation for young and women entrepreneurs. As a result, young and women entrepreneurs may be unfairly treated and denied access to finance to fund their start-ups or undertake initiatives to achieve successful entrepreneurship. Given this corruption too, gender inequality is almost a normalcy in the DRC setting. With this range of challenges, it is not surprising that these entrepreneurs are unsuccessful.

\section{References}

[1] International migration report 2017: Highlights (2017). United Nations. New York: United Nations. Available at: https://www. un.org/en/development/desa/population/migration/publications/migrationreport/docs/MigrationReport2017_Highlights.pdf Last accessed: 07.04.2019

[2] The pursuit of gender equality: an uphill battle (2017). Paris: OECD Publishing. doi: http://oi.org/10.1787/9789264281318-en

[3] Herderschee, J., Kaiser, K. A., Samba, D. M. (2012). Resilience of an African giant. Boosting growth and development in the Democratic Republic of Congo. Washington: World Bank. doi: http://doi.org/10.1596/978-0-8213-8909-6

[4] DR Congo: Ending the cycle of violance in Ituri (2020). Africa report No 292. DR Congo department of justice. International Crisis Group. Available at: https://www.justice.gov/eoir/page/file/1296641/download Last accessed: 02.04.2021

[5] Toma, S.-G., Grigore, A.-M., Marinescu, P. (2014). Economic Development and Entrepreneurship. Procedia Economics and Finance, 8 (14), 436-443. doi: http://doi.org/10.1016/s2212-5671(14)00111-7

[6] Worldometer elaboration of the latest United Nation data, the current population of DR, Congo (2021). United Nations. Available at: https://www.worldometers.info/world-population/democratic-republic-of-the-congo-population/ Last accessed: 31.03 .2021

[7] Definition of ‘youth' (2014). Congo Kinshasa. Available at: https://www.youthpolicy.org/factsheets/country/congo-kinshasa/ Last accessed: 16.01 .2020

[8] Schaumburg-Müller, H., Jeppesen, S., Langevang, T. (2010). Entrepreneurship development in Africa. Report from a workshop, 6-8 September 2010. CBDS Working Paper No. 12/2010. Coperhagen Business School. Available at: https://research-api.cbs. dk/ws/portalfiles/portal/58916968/UM_CBDS_UM_Entrepreneurship_Workshop_final_report.pdf Last accessed: 29.12.2018

[9] Iwu, C. G., Opute, A. P. (2019). Eradicating Poverty and Unemployment: Narratives of Survivalist Entrepreneurs. Journal of Reviews on Global Economics, 8, 1438-1451. doi: http://doi.org/10.6000/1929-7092.2019.08.127

[10] Mongane, C. E., Aganze, K. I. (2017). Disposition on young people to become entrepreneurs in Bukavu town- Democratic Republic of Congo. International research symposiu. Available at: https://www.researchgate.net/publication/324151789_Disposition_of_Young_People_to_become_Entrepreneurs_in_Bukavu_town-Democratic_Republic_of_Congo Last accessed: 03.04.2021

[11] Flavia, J. (2012). Importance of business activities in the country. Available at: https://www.kenyaplex.com/resources/5973-importance-of-business-activities-in-the-country.aspx Last accessed: 19.08.2018

[12] Silverman, D. (2016). Qualitative Research. London: SAGE Publications Inc.

[13] Irene, B. N., Opute, A. P., Ibidunni, A. S. (2020). Competency-Based Entrepreneurship Education: Analysis of the Disruptive Innovation Theory in African HEIs. International Journal of Business and Globalisation.

[14] Etim, E., Iwu, C. G. (2019). A descriptive literature review of the continued marginalisation of female entrepreneurs in sub-Saharan Africa. International Journal of Gender Studies in Developing Societies, 3 (1), 1. doi: http://doi.org/10.1504/ ijgsds.2019.096755

[15] Guzzo, R. A., Jackson, S. E., Katzell, R. A. (1987). Meta-analysis analysis. Research in Organizational Behavior, 9 (1), $407-442$.

[16] Sharma, A., Zhang, Z., Rai, R. (2021). The interpretive model of manufacturing: a theoretical framework and research agenda for machine learning in manufacturing. International Journal of Production Research, 59 (16), 4960-4994. doi: http://doi.org/ $10.1080 / 00207543.2021 .1930234$

[17] King, W. R., He, J. (2005). Understanding the Role and Methods of Meta-Analysis in IS Research. Communications of the Association for Information Systems, 16. doi: http://doi.org/10.17705/1cais.01632

[18] Podsakoff, P. M., MacKenzie, S. B., Bachrach, D. G., Podsakoff, N. P. (2005). The influence of management journals in the 1980s and 1990s. Strategic Management Journal, 26 (5), 473-488. doi: http://doi.org/10.1002/smj.454 
[19] Harb, Y., Abu-Shanab, E. (2020). A descriptive framework for the field of knowledge management. Knowledge and Information Systems, 62 (12), 4481-4508. doi: http://doi.org/10.1007/s10115-020-01492-x

[20] Opute, A. P., Irene, B. N., Iwu, C. G. (2020). Tourism service and digital technologies: A value creation perspective. African Journal of Hospitality, Tourism and Leisure, 9 (2), 1-18.

[21] Opute, A. P., Iwu, C. G., Adeola, O., Mugobo, V., Okeke-Uzodike, O. E., Fagbola, S., Jaiyeoba, O. (2020). The COVID-19-pandemic and implications for businesses: Innovative retail marketing viewpoint. The Retailand Marketing Review: Special Covid Edition, 16 (3), 85-100.

[22] Dey, I. (2005). Qualitative data analysis. London: Routledge, 293.

[23] Pinelli, M. (2013). Avoiding a lost generation: young entrepreneurs need support. Available at: https://www.wired.com/insights/2013/10/avoiding-a-lost-generation-young-entrepreneurs-need-support/ Last accessed: 11.02.2021

[24] Edelman, L. F., Manolova, T., Shirokova, G., Tsukanova, T. (2016). The impact of family support on young entrepreneurs' start-up activities. Journal of Business Venturing, 31 (4), 428-448. doi: http://doi.org/10.1016/j.jbusvent.2016.04.003

[25] Preisendörfer, P., Bitz, A., Bezuidenhout, F. J. (2012). In search of black entrepreneurship: why is there a lack of entrepref neurial activity among the black population in South Africa? Journal of Developmental Entrepreneurship, 17 (1). doi: http:// doi.org/10.1142/s1084946712500069

[26] Nurlaily, F., Aini, E. K., Asmoro, P. S. (2018). Does family social support affect startup business activities? Russian Journal of Agricultural and Socio-Economic Sciences, 74 (2), 41-54. doi: http://doi.org/10.18551/rjoas.2018-02.06

[27] Purwana, D., Suhud, U., Fatimah, T., Armelita, A. (2018). Antecedents of secondary students' entrepreneurial motivation. Journal of Entrepreneurship Education, 21 (2), 1-7.

[28] Atherton, A. (2006). Should Government be Stimulating Start-ups? An Assessment of the Scope for Public Intervention in New Venture Formation. Environment and Planning C: Government and Policy, 24 (1), 21-36. doi: http://doi.org/10.1068/c0436

[29] Scalling up ecosystems for small businesses in the Democratic Republic of Congo (2019). Whashington: World Bank. Available at: https://padmpme.cd/wp-content/uploads/2020/02/congo_english-1.pdf Last accessed: 17.04.2021

[30] Espoir, C. M., Innocent, A. K. (2017). Disposition of young people to become entrepreneurs in Bukavu town - Democratic Republic of Congo. Paper presented at the 2017 International Research Symposium. Bukavu.

[31] Davies, T. (2018). Business angels in Africa. Available at: https://www.linkedin.com/pulse/business-angels-africa-tomi-davies Last accessed: 11.02.2021

[32] Bookwa, J. B. (2016). Provision of entrepreneurship education in developing countries: focus on Democratic Republic of Congo. Available at: https://jirehbookwa.wordpress.com/2016/06/13/provision-of-entrepreneurship-education-in-developing-countries-focus-on-democratic-republic-of-congo/ Last accessed: 07.07.2019

[33] Zuidberg, D. (2018). The DRC entrepreneurial ecosystem, its challenges and the rationale for the creation of "ingenious city" - an incubation platform in Kinshasa. Available at: https:/static1.squarespace.com/static/5bc4882465019f632b2f8653/t/ 5c7378ee971a18427790b8c0/1551071476214/25+-+The+DRC+startup+ecosystem+and+its+challenges_formatting.pdf Last accessed: 11.02 .2021

[34] Kiuma, K., Kaghoma, C. K., Kalala, J. M., Kabamba, A. (2015). Internal mobility and youth entrepreneurship in Democratic Republic of Congo. Working Paper 2015-07. Available at: https://media.africaportal.org/documents/uploads_Project_-_12488_1480366668_-_PMMA-12488-ApprovedWP_English.pdf Last accessed: 26.09.2019

[35] Hoebeke, H., Cintu, P. R. (2016). Hungry for change: the economics underlying DR Congo's political crisis. African Arguments. Available at: https://africanarguments.org/2016/12/hungry-for-change-the-economics-underlying-dr-congos-political-crisis/ Last accessed: 14.07.2018

[36] Women's financial inclusion in the Democratic Republic of Congo. New face new voice Canada, women in finance (2020). International Development Research Centre. Available at: https://idl-bnc-idrc.dspacedirect.org/bitstream/handle/10625/59153/59307.pdf Last accessed: 28.04.2021

[37] Kyamusugulwa, P. M, Hilhorst, D., Bergh, S. I. (2019). Pathways to women's empowerment: Navigating the hybrid social order in eastern DRC. Working Paper 76. London: Secure Livelihoods Research Consortium. Available at: https://reliefweb.int/sites/ reliefweb.int/files/resources/Hybrid-social-orders-patrick-wp-final-online.pdf Last accessed: 12.05.2019

[38] Education in the Democratic Republic of Congo: priorities and options for regeneration (2005). Washington: World Bank. Available at: http://documents1.worldbank.org/curated/en/277181468025495019/pdf/343810PAPER0DR101OFFICIAL0USE0ONLY1.pdf Last accessed: 19.09.2020

[39] Meysonnat, A. Torrano, I. (2020). GPE country-level prospective evaluation year 2: Democratic Republic of Congo. Prospective evaluation of GPE's country*level support to education. Final year report 2020. Available at: https://www.globalpartnership.org/sites/default/files/document/file/2020-07-07-Country-level-prospective-evaluation-year-2-democratic-republic-congo.pdf Last accessed: 07.05.2021 
[40] Groleau, G. (2017). Improved management and accountability: conditions for better access and quality of primary education in the Democratic Republic of Congo? New York: International Rescue Committee. Available at: https://www.rescue.org/sites/ default/files/document/1310/drceducationgovernancefinaljanuary2017.pdf Last accessed: 20.01.2019

[41] Visser, M., Fenning, C. (2018). GPE country level prospective evaluations: first annual report on the Democratic Republic of Congo. Available at: https://www.globalpartnership.org/sites/default/files/2019-03-gpe-drc-cle-report.pdf Last accessed: 11.11.2019

[42] Report: Democratic Republic of Congo (DRC) (2020). EASO. Medical country of origine information. Available at: https:// www.ecoi.net/en/file/local/2042059/2020_DRC_MedCOI_report.pdf Last accessed: 18.04.2021

[43] Country gender profile. Democratic Republic of the Congo. Final report (2017). Japan International Cooperation Agency Country. Tokyo: JICA. Available at: https://www.jica.go.jp/english/our_work/thematic_issues/gender/background/c8h0vm0000anjqj6-att/drc_2017.pdf Last accessed: 03.02.2019

[44] Evaluation of the H4+ joint program Canada and Sweden (SIDA) 2011-2016. Democratic Republic of Congo (2017). United Nations Population Fund. New York: UNFPA. Available at: https://www.unfpa.org/sites/default/files/admin-resource/H4JPCS DRC_Country_Note_Final.pdf Last accessed: 14.03.2019

[45] Partow, H. (2011). Water issues in the Democratic Republic of the Congo: challenges and opportunities. Technical report. Nait robi: UNEP. https://postconflict.unep.ch/publications/UNEP_DRC_water.pdf Last accessed: 23.06.2020

[46] Bokor, B. (2020). Water crisis in the Democratic Republic of Congo. $50 \%$ of Africa's water reserves are located within Congo, yet 51 million people living in rural areas still lack access to quality water. Available at: https://storymaps.arcgis.com/stories/ cf3b87cebc274bd499084f532fb6d910 Last accessed: 25.04.2021

[47] DRC Multisectoral technical Assistance Project (P171762). Project Information Document (PID). Report No PIDC27619. (2019). Washington: World Bank. Available at: https:/documents.worldbank.org/en/publication/documents-reports/documentdetail/793571575917022776/concept-project-information-document-pid-drc-multisectoral-technical-assistance-project-p171762

[48] World economic situation and prospects 2018 (2018). United Nations. Available at: https://www.un.org/development/desa/ dpad/wp-content/uploads/sites/45/publication/WESP2018_Full_Web-1.pdf Last accessed: 26.08.2019

[49] World food programme (2020). Evaluation of Democratic Republic of the Congo, Interim country strategic plan 2018-2020. Saving lives, changing lives. Evaluation report Vol. I. Available at: https:/docs.wfp.org/api/documents/WFP-0000119817/ download/ Last accessed: 22.04.2021

[50] Weijs, B., Hilhorst, D., Ferf, A. (2012). Livelihoods, basic services and social protection in the Democratic Republic of Congo. Secure Livelihoods Research Consortium, Working Paper 2. London: Secure Livelihoods Research Consortium. Available at: https://www.refworld.org/pdfid/523ad5534.pdf Last accessed: 11.03.2019

[51] Democratic Republic of Congo systematic country diagnostic: policy priorities for poverty reduction and shared prosperity in a post-conflict country and fragile state (2018). Washington: World Bank. Available at: https://openknowledge.worldbank. org/bitstream/handle/10986/30057/DRC-SCD-FINAL-ENGLISH-06132018.pdf?sequence=1\&isAllowed=y Last accessed: 07.04.2019

[52] Democratic Republic of Congo country strategic plan 2021-2024 (2020). World Food Programme. Available at: https://reliefweb.int/sites/reliefweb.int/files/resources/WFP-0000119408.pdf Last accessed: 18.03.2021

[53] Muriithi, S. (2017). African small and medium enterprises (SMEs): contributions, challenges and solutions. European Journal of Research and Reflection in Management Sciences, 5 (1), 36-48.

[54] Cant, M. C., Wiid, J. A. (2013). Establishing The Challenges Affecting South African SMEs. International Business \& Economics Research Journal (IBER), 12 (6), 707-716. doi: http://doi.org/10.19030/iber.v12i6.7869

[55] Doing business (2020). Washington DC: World Bank. http://documents1.worldbank.org/curated/en/688761571934946384/pdf/ Doing-Business-2020-Comparing-Business-Regulation-in-190-Economies.pdf Last accessed: 02.12.2020

[56] Democratic Republic of the Congo age structure 2020 (2020). Index Mundi. https://www.indexmundi.com/democratic_republic_of_the_congo/age_structure.html Last accessed: 13.05.2021

[57] Kisangani, E. (2012). Book review: Civil wars in the Democratic Republic of Congo, 1960-2010. London: Lynne Rienner. African Journal on Conflict Resolution, 13 (2). Available at: https://www.accord.org.za/ajcr-issues/civil-wars-in-the-democratic-republic-of-congo-1960-2010/ Last accessed: 29.12.2018

[58] Englebert, P.; Cavelty, M. D., Balzacq, T. (Eds.) (2016). Conflict in the democratic Republic of Congo. The Routledge handbook of security studies. Abingdon: Routledge, 340-349. doi: http://doi.org/10.4324/9781315753393-40

[59] The Democratic Republic of the Congo. Post-conflict environmental assessment. Synthesis for policy makers (2011). Nairobi: UNEP. Available at: https://postconflict.unep.ch/publications/UNEP_DRC_PCEA_EN.pdf Last accessed: 16.02.2019

[60] Bertelsmann Stiftung, BTI 2020 country report-Congo, DR (2020). Gutersloh: Bertelsmann Stiftung. 
[61] Wolters, S. (2019). Opportunities and challenges in the DRC. Available at: https://issafrica.org/research/central-africa-report/ opportunities-and-challenges-in-the-drc Last accessed: 18.12.2019

[62] Woldie, A., Mwangaza Laurence, B., Thomas, B. (2018). Challenges of finance accessibility by SMEs in the democratic republic of Congo: is gender a constraint? Investment Management and Financial Innovations, 15 (2), 40-50. doi: http:// doi.org/10.21511/imfi.15(2).2018.04

[63] Women, business and the law 2018 (2018). Washington: World Bank.

[64] Tabares, I. (2015). Comprehensive skills program for emancipated foster youth. A grant thesis project. Long Beach, California State University. Available at: https:/www.proquest.com/openview/260d773e9a96a1fe4fecb38374031ca9/1?pq-origsite=gscholar\&cbl $=18750$

[65] Georgieva, K., Gurria, J. Guterres, A. (2011). Supporting the development of more effective tax systems: a report to the G-20 development working group by the IMF, OECD, UN and World Bank. Available at: http://www.oecd.org/ctp/48993634.pdf Last accessed: 11.11.2019

[66] Paler, L., Prichard, W., Sanchez de la Sierra, R., Samii, C. (2017). Survey on total tax burden in the DRC: final report. Prepared for Department of International Development. Available at: https:/www.ictd.ac/wp-content/uploads/2019/06/DFID_DRC_ TaxBurden_Final.pdf Last accessed: 18.02.2019

[67] Lampietti, J., Stalker, L. (2000). Consumption expenditure and female poverty: a review of the evidence. Policy research report on gender and development. Poverty reduction and economic management network. Working Paper Series No. 11. Washington: World Bank.

[68] Myint, U. (2000). Corruption: causes, consequences, and cures. Asia Pacific Development Journal, 7 (2), $33-58$.

[69] Kar, D., LeBlanc, B. (2014). Illicit financial flows to and from the Philippines: a study in dynamic simulation: 1960-2011. Washington: Global Financial Integrity. Available at: https://www.gfintegrity.org/wp-content/uploads/2014/05/Illicit-Financial-Flows-to-and-from-the-Philippines-Final-Report.pdf Last accessed: 30.04.2019

[70] Epaphra, M., Massawe, J. (2017). Corruption, governance and tax revenues in Africa. Business and Economic Horizons, 13 (4), 439-467. doi: http://doi.org/10.15208/beh.2017.31

[71] Chêne, M. (2010). Overview of corruption and anti-corruption in the Democratic Republic of Congo (DRC). Transparency International No. 257. U4 Anti-Corruption Resource Centre. Bergen: CMI. Available at: https://assets.publishing.service.gov. uk/media/57a08af3e5274a27b2000875/expert-helpdesk-257.pdf Last accessed: 24.12.2018

[72] Lee-Jones, K. (2020). Anti-Corruption Resource Centre. The Democratic Republic of Congo: overview of corruption and ane ti-corruption. Transparency International. Available at: https://www.u4.no/publications/democratic-republic-of-congo-overview-of-corruption-and-anti-corruption Last accessed: 03.05.2021

[73] 4 top investment opportunities in the DRC (2013). Available at: https:/www.africa.com/top-4-investment-opportunities-in-the-drc Last accessed: 28.11.2018

[74] Emid, A. (2018). Democratic Republic of Congo: rich nation, risk nation. Global Finance. Available at: https://www.gfmag. com/magazine/may-2018/dr-congo Last accessed: 26.07.2019

[75] Validation of the Democratic Republic of Congo. International secretariat. Report on initial data collection and stakeholder consultation (2019). EITI. Available at: https://eiti.org/files/documents/drc_2018_validation_initial_assessment_final_ april_2019.pdf Last accessed: 11.05.2021

[76] The Democratic Republic of Congo: country mining guide (2014). KPMG Global Mining Institute. Available at: https:/assets.

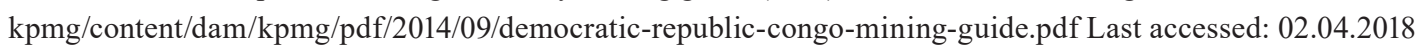

[77] Hanafi, A., Hurley, J., Martin, L., McGrenra, D. (2019). Democratic Republic of the Congo. Country Strategic Opportunities Programme 2019-2024. Available at: https://www.gtai.de/resource/blob/153868/cbb60alc54554067b3014c8d5ed9bbfc/ pro201909035040-data.pdf Last accessed: 26.09.2020

[78] Esipova, N. (2017). Gallup report. Towards a better future for women and work: voices of women and men. Washington: Gallup World; Geneva: International Labour Organization. Available at: https://www.ilo.org/wcmsp5/groups/public/---dgreports/--dcomm/---publ/documents/publication/wcms_546256.pdf Last accessed: 01.11.2019

[79] World employment social outlook: trends 2018. (2018). Geneva: ILO. Available at: https:/www.ilo.org/wcmsp5/groups/public/--dgreports/---dcomm/---publ/documents/publication/wcms_615594.pdf Last accessed: 22.05.2019

[80] State of skills, the Democratic Republic of the Congo (2019). ILO (International Labour Organization). Available at: https:// www.ilo.org/wcmsp5/groups/public/---ed_emp/---ifp_skills/documents/genericdocument/wcms_742204.pdf Last accessed: 22.04.2021

[81] Wright, E. (2015). How poverty encourages generational prostitution in India. Available at: https://borgenproject.org/prostitution-in-india/ Last accessed: 14.03.2019

[82] Murhula, J. L. (2006). Minerals, forests, and violent conflict in the Democratic Republic of the Congo. ECSP Report, 12, 2-19. 
[83] Schulze, E., Canto, S. I. N., Mason, P., Skalin, M. (2014). Sexual exploitation and prostitution and its impact on gender equality. Brussels: European Parliament. Available at: http://www.europarl.europa.eu/RegData/etudes/etudes/join/2014/493040/IPOL-FEMM_ET(2014)493040_EN.pdf Last accessed: 07.07.2019

[84] Stoebenau, K., Heise, L., Wamoyi, J., Bobrova, N. (2016). Revisiting the understanding of "transactional sex" in sub-Saharan Africa: A review and synthesis of the literature. Social Science \& Medicine, 168, 186-197. doi: http://doi.org/10.1016/ j.socscimed.2016.09.023

[85] Mwapu, I., Hilhorst, D., Mashanda, M., Bahananga, M., Mugenzi, R. (2016). Women engaging in transactional sex and working in prostitution: practices and underlying factors of the sex trade in South Kivu, the Democratic Republic of Congo. Secure Livelihoods Research Consortium, Report 10. Available at: https://assets.publishing.service.gov.uk/media/57a08964e5274a31e0000062/SLRC-Report-10-Congo-TransactionalSex-LowRes.pdf Last accessed: 30.01.2019

[86] Leclerc-Madlala, S. (2004). Transactional sex and the pursuit of modernity. CSSR Working Paper No. 68. Centre for Social Science Research, University of Cape Town. Available at: https://open.uct.ac.za/bitstream/handle/11427/19269/Leclerc_Madlala_Transactional_2004.pdf?sequence=1\&isAllowed=y Last accessed: 29.07.2019

[87] DemocraticRepublic ofCongo,HumanitariansituationreportNo09UNICEF(2020).UNICEF.Availableat:https://www.unicef.org/ media/89516/file/UNICEF-DRC-Humanitarian-Situation-Report-No.-9-September-2020.pdf Last accessed: 07.05.2021

[88] Tate, T., Stauss, K., Mwezi, J. B. D., Bleasdale, M. (2006). What future? Street children in the Democratic Republic of Congo. New York: Human Rights Watch.

[89] Rakisits, C. (2008). Child Soldiers in the East of the Democratic Republic of the Congo. Refugee Survey Quarterly, 27 (4), 108-122. doi: http://doi.org/10.1093/rsq/hdn054

[90] Makelele, B. M. (2018). Etiology of juvenile criminality in Kinshasa Said Kuluna phenomenon. American Journal of Applied Psychology, 6 (1), 14-22.

[91] Kobler, B., Lattes, P., Hovy, B. (2017). International migration report 2017: Highlights. New York: United Nations. Available at: https://www.un.org/en/development/desa/population/migration/publications/migrationreport/docs/MigrationReport2017_ Highlights.pdf Last accessed: 26.11.2019

[92] Sumata, C., Cohen, J. H. (2018). The Congolese diaspora and the politics of remittances. Remittances Review, 3 (2), $95-108$. doi: http://doi.org/10.33182/rr.v3i2.567

[93] Flahaux, M. L., Schoumaker, B. (2016). Democratic Republic of Congo: a migration history marked by crises and restrictions. Washington: Migration Policy Institute. Available at: https://www.migrationpolicy.org/article/democratic-republic-congo-migration-history-marked-crises-and-restrictions Last accessed: 27.07.2018

[94] Ramos, C. (2019). Unsafe Return III. Removals to the Democratic Republic of Congo 2015-2019. Available at: https://cityofsanctuary.org/wp-content/uploads/2019/05/Unsafe-Return-III-Removals-to-the-Democratic-Republic-of-the-Congo-2015-to2019-Catherine-Ramos.pdf Last accessed: 04.10.2020

[95] Democratic Republic of Congo Urbanization Review: Productive and Inclusive Cities for an Emerging Democratic Republic of Congo. Direction in Development (2018). Washington: World Bank. Available at: https://openknowledge.worldbank.org/ bitstream/handle/10986/28931/9781464812033.pdf?sequence=2\&isAllowed=y Last accessed: 29.04 .2021

[96] Democratic Republic of Congo. Economic and Sector Work. Regional economic development in Bas Congo in the context of decentralization in the Democratic Republic of Congo (DRC) (2009). African Development Bank \& African Development Fund. Available at: https://www.afdb.org/fileadmin/uploads/afdb/Documents/Project-and-Operations/DRC_Etude\%20decentralisation_english__01.pdf Last accessed: 14.09.2019

[97] Democratic Republic of Congo urbanization review. Productive and inclusive cities for an emerging Democratic Republic of Congo (2017). Washington, : World Bank. doi: http://doi.org/10.1596/978-1-4648-1203-3

[98] Stearns, J. (2012). North Kivu: the background to conflict in North Kivu province of eastern Congo. London: Rift Valley Institute.

[99] Van Laer, V., Zakaryan, T., Hovil, L., Lambe, A. (2018). Conflict and displacement in the Kasai. Kampala: International Refugee Rights Initiative. Available at: https://reliefweb.int/sites/reliefweb.int/files/resources/Kasai-report-IRRI-ENG.pdf Last accessed: 18.03.2019

[100] Bastian, B .L., Metcalfe, B. D., Zali, M. R. (2019). Gender inequality: entrepreneurship development in the MENA region. Sustainability, 11 (22). doi: http://doi.org/10.3390/su11226472

[101] Mini grid opportunity assessment: Democratic Republic of the Congo (2017). Abidjan: African Development Bank. Available at: https://greenminigrid.afdb.org/sites/default/files/Mini-grid\%20DRoC.pdf Last accessed: 08.03.2019

[102] Selimovic, J., Brandt, A., Söderberg-Jacobson, A. S. (2018). Equal power - Lasting peace. The Democratic Republic of Congo. No peace for women. Obstacles for women's participation in peace processes. Johanneshov: Kvinna till Kvinna Foundation. 
Available at: https://kvinnatillkvinna.org/wp-content/uploads/2018/10/13-Equal-power-lasting-peace-DRC_ENG.pdf Last accessed: 27.08.2019

[103] Peterman, A., Palermo, T., Bredenkamp, C. (2011). Estimates and Determinants of Sexual Violence Against Women in the Democratic Republic of Congo. American Journal of Public Health, 101 (6), 1060-1067. doi: http://doi.org/10.2105/ ajph.2010.300070

[104] Ragasa, C., Kinwa-Muzinga, A., Ulimwengu, J. (2012). Gender assessment of the agricultural sector in the Democratic Republic of Congo. IFPRI Discussion Paper 01201. Washington: IFPRI. Available at: http:/ebrary.ifpri.org/utils/getfile/collection/ p15738coll2/id/127065/filename/127276.pdf Last accessed: 28.02.2019

[105] Project information document/Integrated safeguards data sheet (PID/ISDS). Report No: PIDISDSC20568. Democratic Republic of Congo - SME Development and Growth Project (P160806) (2017). World Bank. Available at: http://documents1. worldbank.org/curated/en/610151502304081524/pdf/ITM00184-P160806-08-09-2017-1502304076949.pdf Last accessed: 23.08.2019

[106] Schwarz, S. (2011). Financial institutions' challenges to provide credit in the Democratic Republic of Congo - Experiences from financial cooperation. Frankfurt am Main: KfW Bankengruppe. Available at: https:/www.kfw-entwicklungsbank.de/ Download-Center/PDF-Dokumente-Sektoren-Berichte/2011_06_Congo-Kredit_E.pdf Last accessed: 18.02.2019

[107] Lukamba-Muhiya, J. M., Uken, E. (2006). The electricity supply industry in the Democratic Republic of the Congo. Journal of Energy in Southern Africa, 17 (3), 21-28. doi: http://doi.org/10.17159/2413-3051/2006/v17i3a3261

[108] Opute, A. P., Kalu, K. I., Adeola, O., Iwu, C. G. (2021). Steering Sustainable Economic Growth: Entrepreneurial Ecosystem Approach. Journal of Entrepreneurship and Innovation in Emerging Economies, 7 (2), 216-245. doi: http://doi. org/10.1177/23939575211024384

[109] Opute, A. P. (2020). Small and medium enterprises marketing: Innovation and sustainable economic growth perspective. Entrepreneurship Marketing, 13-30. doi: http://doi.org/10.4324/9780429505461-2

[110] Iwu, C. G., Eze, F. I., Opute, A. P., Dongo, G. U., Dongo, O. W. (2021). Scavenging for Survival and its Health Implications. The nexus between Unemployment and Ill-health. Wseas transactions on environment and development, 17, 1-8. doi: http:// doi.org/10.37394/232015.2021.17.1

[111] Stoica, O., Roman, A., Rusu, V. D. (2020). The Nexus between Entrepreneurship and Economic Growth: A Comparative Analysis on Groups of Countries. Sustainability, 12 (3), 1186. doi: http://doi.org/10.3390/su12031186

[112] Iwu, C. G., Opute, P. A., Nchu, R., Eresia-Eke, C., Tengeh, R. K., Jaiyeoba, O., Aliyu, O. A. (2021). Entrepreneurship education, curriculum and lecturer-competency as antecedents of student entrepreneurial intention. The International Journal of Management Education, 19 (1), 100295. doi: http://doi.org/10.1016/j.ijme.2019.03.007

How to cite: Lipoko, D. U. D., Iwu, C. G., Opute, A. P. (2021). Gender discrepancy in economic participation: the case of young women in the Democratic Republic of Congo. EUREKA: Social and Humanities, 6, 14-30. doi: http://doi.org/10.21303/2504-5571.2021.002121 